\title{
Amino Acid Solute Carrier Transporters in Inflammation and Autoimmunity
}

\author{
Linlin Sheng $^{1 \#}$, Qi Luo ${ }^{1 \#}$, Ligong Chen ${ }^{1,2,3^{*}}$
}

${ }^{1}$ School of Pharmaceutical Sciences, Key Laboratory of Bioorganic Phosphorus Chemistry and Chemical Biology (Ministry of Education), Tsinghua University, Beijing, China

${ }^{2}$ Advanced Innovation Center for Human Brain Protection, Beijing Tiantan Hospital, Capital Medical University, Beijing, China

${ }^{3}$ Collaborative Innovation Center for Biotherapy, State Key Laboratory of Biotherapy and Cancer Center, West China Hospital, West China Medical School, Sichuan University, Chengdu, China

${ }^{\#}$ Contributed equally 


\title{
Amino Acid Transporters in Immunity
}

*Correspondence: Ligong Chen

ligongchen@tsinghua.edu.cn

Text pages: 14

Table: 2

Figures: 2

References: 134

Abstract: 183 words

Introduction: 515 words

Conclusion: 92 words

\begin{abstract}
Abbreviations
$\mathrm{AD}$, Alzheimer's disease; CAC, colitis-associated carcinogenesis; $\mathrm{CD}$, Crohn's disease; CRC, colorectal cancer; CLL, chronic lymphocytic leukemia; CNS, central nervous system; CSC, cancer stem cells; GS, glutamine synthetase; HERV, human endogenous retrovirus; HIEs, human intestinal enteroids; HIV, human immunodeficiency virus; HOXB9, homeobox B9; HUVEC, human saphenous vein endothelial cells; IBD, Inflammatory bowel disease; JEV, Japanese encephalitis virus; KSHV, Kaposi’s sarcomaassociated herpesvirus; LPI, lysinuric protein intolerance; MDSCs, myeloid-derived suppressor cells; MS, multiple sclerosis; NFAT, nuclear factor of activated T cells; RA, rheumatoid arthritis; SLCs, solute carriers; T-ALL, T-cell acute lymphoblastic leukemia; TCR, T cell receptor; UC, ulcerative colitis; VSV, vesicular stomatitis virus; WNV, West Nile virus.
\end{abstract}

\section{Contents:}




\section{Abstract}

Introduction

SLCs function in innate and adaptive immune cells

SLCs in neural inflammation and autoimmunity (multiple sclerosis)

SLCs during infection

SLCs in other chronic or autoimmune diseases

SLC-targeted therapeutics and conclusion

Acknowledgments

Authorship Contributions

References

Footnotes

Figure Legends

Tables

Figures 


\begin{abstract}
The past decade exposed the importance of many homeostasis and metabolism related proteins in autoimmunity disease and inflammation. Solute carriers (SLCs) are a group of membrane channels that can transport amino acids, the building blocks of proteins, nutrients, and neurotransmitters. This review summarizes the role of SLCs amino acid transporters in inflammation and autoimmunity disease. In detail, the importance of Glutamate transporters SLC1A1, SLC1A2, and SLC1A3, mainly expressed in the brain where they help prevent glutamate excitotoxicity, is discussed in the context of central nervous system (CNS) disorders such as multiple sclerosis. Similarly, the cationic amino acid transporter SLC7A1 (CAT1), which is an important arginine transporter for T cells, and SLC7A2 (CAT2), essential for innate immunity. SLC3 family proteins, which bind with light chains from the SLC7 family (SLC7A5, SLC7A7 and SLC7A11) to form heteromeric amino acid transporters, are also explored to describe their roles in $\mathrm{T}$ cells, NK cells, macrophages and tumor immunotherapies. Altogether, the link between SLC amino acid transporters with inflammation and autoimmunity may contribute to a better understanding of underlying mechanism of disease and provide novel potential therapeutic avenues.

SIGNIFICANCE STATEMENT In this review, we summarize the link between SLC amino acid transporters and inflammation and immune responses, specially SLC1 family members and SLC7 members. Studying the link may contribute to a better understanding of related diseases and provide potential therapeutic targets and useful to the researchers who have interest in the involvement of amino acids in immunity.
\end{abstract}




\section{Introduction}

Nearly half of all deaths worldwide are attributed to chronic inflammatory conditions(Furman et al,2019). In fact, one in every five Americans suffers from at least one chronic inflammatory condition, and 3-5\% of an autoimmunity disorder(Wang et al,2015). Traditionally, inflammatory and metabolic diseases were often approach separately, but the past decades have highlighted the importance of metabolic dysbiosis in chronic inflammation and autoimmunity disorders(Compston and Coles,2008, Sospedra and Martin,2005, Pitt et al,2000). For example, multiple sclerosis (MS) is exacerbated by excessive glutamate transport and excitotoxicity, mediated by SLC proteins. Similarly, L-arginine transport, also mediated by SLCs, regulates multiple innate inflammatory mechanisms such of arginase-1 (ARG1) activity and inducible nitric oxide synthase (iNOS, NOS2).

The SLC superfamily is a large group of membrane transporters with over 65 families and more than 400 members. SLCs play important roles in nutrient and metabolic sensing(Zhang et al,2019, Chen et al,2019), and metabolic regulation of immune cells(Song et al,2020). Structurally SLCs can be tremendously diverse with a myriad of substrates; and while several SLCs act as drug transporters(Liang et al,2015), many others can transport amino acid across membranes, such as members of SLC1 and SLC7 families (Table 1).

The SLC1 family of transporters, named high-affinity glutamate and neutral amino acid transporter family, comprises five excitatory amino acid transporters (EAATs) of the $\mathrm{X}_{\mathrm{AG}}^{-}$system, and two alanine serine cysteine transporters (ASCTs) of the ASC system. The ASC system includes the two neutral amino acid transporters of the SLC1 family, SLC1A4 (ASC transporter 1) and SLC1A5 (ASC transporter 2)(Kanai et al,2013). The $\mathrm{X}_{\mathrm{AG}}^{-}$system includes SLC1A1 (EAAC1), SLC1A2 (GLT1, EAAT2), SLC1A3 (GLAST, EAAT1), SLC1A6 (EAAT4) and SLC1A7 (EAAT5), which are high-affinity glutamate transporters responsible for L-glutamate and D/L-aspartate uptake with cotransport of three sodium ions $\left(\mathrm{Na}^{+}\right)$and one proton $\left(\mathrm{H}^{+}\right)$, and counter-transport of one potassium ion $\left(\mathrm{K}^{+}\right)($Kanai et al,2013). In the brain, SLC1A1 is mainly expressed in neurons; SLC1A2 in astrocytes, Bergmann glia and neurons; and 
SLC1A3 in astrocytes and Bergmann glia(Kanai et al,2013), all with important functions in the CNS (Figure 1).

The SLC7 family of transporters, named cationic amino acid transporter/glycoprotein-associated family, are divided into two subfamilies: the cationic amino acid transporters (CATs), and the L-type amino acid transporters (LATs). CATs include SLC7A1-4 and SLC7A14, which mediate $\mathrm{Na}^{+}$independent transport of cationic L-amino acids(Fotiadis et al,2013); while LATs are the light or catalytic subunits of heteromeric amino acid transporters (HATs) with a broad spectrum of substrates(Fotiadis et al,2013), which are linked to the heavy subunits $4 \mathrm{~F} 2 \mathrm{hc}(\mathrm{SLC} 3 \mathrm{~A} 2)$ or $\mathrm{rBAT}(\mathrm{SLC} 3 \mathrm{~A} 1)$ through disulfide bonds. SLC7 transporters are important metabolic regulators in immune cells as summarized in Figure 2.

In this review, the role of SLCs amino acids transporters in inflammation and autoimmunity and its supporting literature discussed in detail. First, the part of SLC7 family members in innate and adaptive immune cells is debated, followed by the importance of SLC1 family proteins in neural inflammation, particularly in MS. Similarly, the role of SLCs in viral and bacterial infections is also analyzed, along with a brief summary on the impact of SLCs in other inflammatory disorders. Finally, the prospect of SLC based therapeutics is explored.

\section{SLCs function in innate and adaptive immune cells}

The immune system is a complex biological network, traditionally separated in innate and adaptive immune cells. Innate immune cells such as Macrophages, Dendritic cells and NK cells are generally the first responders, driving inflammation through antigen-independent mechanisms. Adaptive immune cell, such as $\mathrm{T}$ and $\mathrm{B}$-cells, are activated by innate immune signals and drive antigen-specific memory immunity.

SLC7A2 is highly involved in both innate and adaptive immunity. Slc7a2 expression was induced in both classical (M1) and alternative (M2) activated in macrophages, and Slc7a2 knockout blocked arginine transport and limited its activity after macrophage activation(Yeramian et al,2006). Furthermore, 
Platonin, an inhibitor of acute inflammation, lowered NO production and arginine transport in LPSstimulated mouse macrophages via iNOS and SLC7A2 inhibition(Chen et al,2006). Slc7a2 expression in peripheral monocytes was also found to be upregulated in pregnancy and was higher in preeclampsia, during which systemic inflammation is widespread and the arginine transport is strengthened(McCord et al,2006). The lung of SLC7A2 deficient mice show signs of spontaneous inflammation accompanied by increased DC and alveolar macrophages activation, but with compromised NO production(Rothenberg et al,2006). Finally, Myeloid-derived suppressor cells (MDSCs) suppressed $\mathrm{T}$ cell activities under inflammation or tumor conditions through increased arginine metabolism, while SLC7A2 deficiency promoted antitumor immunity(Bozkus et al,2015).

Epithelial and endothelial cells also contribute for early innate inflammatory signals. In endothelial cells, human saphenous vein endothelial cells (HUVEC) stimulated by TNF- $\alpha$ showed higher Slc7a2 expression(Knyazev et al,2018); similarly, HSVEC stimulated by TNF- $\alpha$ showed elevated SLC7A2

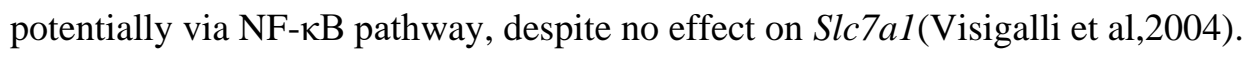

SLC7A7 also affects amino acid transport, differentiation and immune function of macrophages. Slc7a7 mRNA, SLC7A7 protein levels and arginine transport were increased during monocyte differentiation to macrophages mediated by PKC activation. Contrastingly, the $\mathrm{y}^{+}$system and $\mathrm{y}^{+} \mathrm{L}$ system mainly transported arginine and lysine outwards of macrophagic cells(Barilli et al,2011). Silencing of Slc7a7 in human THP-1 macrophages and A549 epithelial cells induced secretion of IL-1 $\beta$, and TNF- $\alpha$ via the NF$\kappa \mathrm{B}$ pathway, and CCL5/RANTES stimulated by IL-1 $\beta$ signaling feedback, which were independent of arginine concentration. Thus, Slc7a7 likely plays a deeper role in inflammation aside of arginine transport(Rotoli et al,2018). Mutation of Slc7a7 could also cause lysinuric protein intolerance (LPI), in which arginine transport by system $\mathrm{y}^{+} \mathrm{L}$ was impaired in macrophages and phagocytic activity was severely damaged(Barilli et al,2012). In LPI patients, plasma pro-inflammatory chemokines were higher, and LPI macrophages exhibited impaired response to TLR9 stimulation, higher response to TLR2/1 and TLR4 stimulation, and lower NO production(Kurko et al,2015). 
SLC7A5 mediated leucine transport in macrophages promoted mTORC1 signaling and pro-inflammatory cytokine production(Yoon et al,2018). Slc7a5 expression was upregulated in monocytes from rheumatoid arthritis (RA) patients and healthy monocytes following LPS stimulation. Additionally, Slc7a5 expression levels positively correlated with RA clinical condition indicating a relationship of SLC7A5 with inflammation(Yoon et al,2018). Similarly, a natural alkaloid piperine promoted mTORC1 signaling via recruitment of membrane SLC7A5/CD98, synthesis of IL-6 and TNF- $\alpha$, and phagocytic activity against bacteria in peritoneal macrophages(Pan et al,2015). In activated NK cells, SLC7A5 also acted as a predominant amino acid transporter and together with glutamine supply, was essential for maintaining cMyc and NK cell function(Loftus et al,2018).

Still in macrophages, treatment with amphibole asbestos increased SLC7A11 expression, while SLC7A11 inhibition led to oxidative stress and cell death, which could be rescued by cystine(Pfau et al,2012). SLC7A11 was identified as a macrophagic host factor in the vesicular stomatitis virus (VSV) replication(Kandasamy et al,2016), and in LPS-stimulated macrophages, SLC7A11 deficiency caused insufficient cysteine supply, decreased nitrite in the culture medium and an increase in reactive oxygen species (ROS)(Kobayashi et al,2018). LPS stimulation in hippocampus elevated SLC7A11 expression, and knockout of SLC7A11 relieves peripheral and central inflammation and the effect of LPS stimulation in mice(Albertini et al,2018). SLC7A11 was also elevated in IL-4-induced M2 macrophages during parainflammation and is related to M2 genes(Wang et al,2020a).

SLC7A11 $(\mathrm{xCT})$ forms system $\mathrm{x}_{\mathrm{c}}{ }^{-}$with CD98 and is mainly expressed in the brain, macrophages, and cell lines, and acts as a $\mathrm{Na}^{+}$-independent transporter of extracellular anionic cystine and intracellular glutamate(Fotiadis et al,2013). For T cells, although in vitro proliferation was SLC7A11-dependent, in vivo proliferation, immune response, and memory effects were SLC7A11-independent; therefore, using SLC7A11 as an antitumor therapeutic target should not affect $\mathrm{T}$ cell immune response(Arensman et al,2019). Although baseline SLC7A11 levels are relatively low in T cells, thermal injury strongly induces SLC7A11, resulting in cystine import and T cell dysfunction(D'Elia et al,2009). Glutathione (GSH) 
production in part mediated by SLC7A11 can limit ROS accumulation and support the activity of mTOR and nuclear factor of activated $\mathrm{T}$ cells (NFAT) to drive glycolysis and glutaminolysis in activated $\mathrm{T}$ cells(Mak et al,2017).

In NK cells, IL-2 priming could upregulate SLC1A5 and SLC3A2 (CD98), which were both necessary for IFN- $\gamma$ production and degranulation by NK cells following stimulation of the activating receptor, natural-killer group 2 member D (NKG2D)(Jensen et al,2017). SLC1A5 participates in adaptive immunity as a conditionally essential glutamine transporter. SLC1A5-dependent rapid glutamine uptake occurred during naïve T cell activation, and SLC1A5 deficiency caused failure of Th1 and Th17 cell induction, as well as loss of the inflammatory $\mathrm{T}$ cell responses(Nakaya et al,2014). Glutamine uptake through SLC1A5 and T cell receptor (TCR) signaling complex were both necessary for mTORC activation by TCR stimulation(Nakaya et al,2014). Further, glucose and glutamine were both required upon B cell activation(Jiang et al,2018). Overexpression of the microRNA cluster let-7adf reduced levels of both glucose by targeting hexokinase two and glutamate by inhibition of SLC1A5 and glutaminase, and further controlled antibody production of B cells(Jiang et al,2018). However, SLC1A5 knockout in mice was reported to have no influence on B cell development, proliferation, or function(Masle-Farquhar et al,2017). Blocking SLC1A5 with GPNA to inhibit the uptake of glutamine can significantly enhance the inhibitory effect of cetuximab on the proliferation of gastric cancer and metastatic colorectal cancer (CRC) in vivo and in vitro. Research provides the metabolic role of SLC1A5 as potential therapeutic target to improve the efficacy of cetuximab for CRC and gastric cancer (Ma et al,2021, Ma et al,2018).

SLC7A1 seems to be the major system $\mathrm{y}^{+}$transporter in most cell types(Fotiadis et al,2013). SLC7A1 expression was increased in $\mathrm{CD}^{+} \mathrm{T}$ cells and naïve and memory $\mathrm{CD}^{+} \mathrm{T}$ cells to provide sufficient arginine for $\mathrm{T}$ cell function(Werner et al,2016). In contrast, Slc7al expression was not induced by

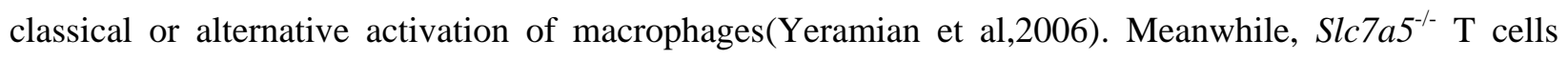
showed impaired proliferation, differentiation or metabolically reprogramming upon antigen stimulation, and leucine transport by L system was required for mTORC1 activity and c-Myc expression in activated 
$\mathrm{T}$ cells(Sinclair et al,2013). The lack of methionine may also be responsible for the halt of protein production in $S l c 7 a 5^{-1-} \mathrm{T}$ cells, similar to the effect of Myc deletion(Marchingo et al,2020). SLC7A5 inhibition as well as amino acid starvation triggered expression of homeobox B9 (HOXB9) in activated T cells, which attenuated production of selective cytokines(Hayashi et al,2016). SLC7A7 participated in the pathogenesis of T-cell acute lymphoblastic leukemia (T-ALL)(Ji et al,2018).

\section{SLCs in neural inflammation and autoimmunity (multiple sclerosis)}

Neurological diseases afflict 3-5\% of the global population. Multiple sclerosis alone affects 59/100 000 habitants in Europe to a total of almost 700000 people in 2017(Deuschl et al,2020). Transient inflammation and restorable neurological dysfunction often occur during early MS stages, although widespread microglial activation and chronic neurodegeneration gradually develop(Compston and Coles,2008). MS has traditionally been considered an autoimmune disease primarily mediated by $\mathrm{CD}^{+}$ Th1 cells, but other immune factors likely influence disease progression. SLC1A2 is expressed in astrocytes, neurons, and axonal terminals where it regulates glutamate concentrations in the CNS, often together with SLC1A3. Thus, these two transporters are mechanistically important in preventing excitotoxicity. In the inflammatory CNS microenvironment of MS, SLC1A3 and SLC1A2 levels and glutamate uptake were elevated in optic nerves and reduced excitotoxicity(Vallejo-Illarramendi et al,2006). In cultured astrocytes, SLC1A3 and SLC1A2 levels were reduced after treatment with proinflammatory cytokines(Lee et al,2017). In cortical lesions of MS brains, activated microglia correlated with decreased levels of SLC1A3, SLC1A2 and synaptophysin, and also elevation of phosphorylated (p)JNK levels in response of excitotoxicity(Vercellino et al,2007). In the inflammation of MS, Th-17 cells function by releasing IL-17A, which promotes glutamate excitotoxicity by decreasing astrocyte SLC1A2, SLC1A3, and glutamine synthetase (GS) expression; and also by stimulating $\mathrm{Ca}^{2+}$-dependent glutamate release, indicating an association between inflammation and neurodegeneration in MS(Kostic et al,2017). In the early stages of neuroinflammation, glutamate released by activated microglia stimulated an increase in extracellular and intracellular glutamate levels of astrocytes and in turn, resulted in reduced astrocytic 
SLC1A3 levels and failure of extracellular glutamate clearance(Takaki et al,2012). SLC1A3 was also upregulated in the hypothalamus of long-living growth hormone receptor (GHR)-KO mice, together with higher expression of hypothalamic NF- $\mathrm{BB}$, IGF-1 receptor, and the GluA1 subunit of the glutamate receptor, AMPAR expression, and lower IL-1 $\beta$ in many brain regions, these data support the importance of decreased brain inflammation in early adulthood and maintained homeostasis of the glutamatergic and inflammatory systems in extended longevity(Hascup et al,2016). In the brain, SLC7A11 participates in glutamate excitotoxicity, mainly by controlling extracellular nonsynaptic glutamate concentration. Upon SLC7A11 upregulation by immune activation, extracellular glutamate rose and led to excitotoxicity(Pampliega et al,2011).

Experimental allergic (autoimmune) encephalomyelitis (EAE) in mice is widely used as a demyelinating model for MS. After EAE induction, mice lacking N-Myc downstream-regulated gene 2 (Ndrg2) maintained more SLC1A3 and SLC1A2, and the inhibitory effect of NDRG2 on EAAT1 expression was dependent on Akt rather than on NF- $\mathrm{B}$ activity(Le et al,2018). SLC1A3 expression can be altered by xenobiotics, and astrocytic SLC1A3 expression was associated with intraperitoneal injection of a synthetic Toll-like receptor (TLR)-3 ligand, polyinosinic acid, which also promoted IFN- $\beta$ transcription in the CNS(Costello and Lynch,2013). Moreover, dietary cocoa stimulated SLC1A3 expression, while suppressing inflammatory cytokine expression during prolonged activation of trigeminal ganglion neurons and glia by complete Freund's adjuvant(Cady et al,2013); while Acrolein, a neurotoxin produced in the brain during ischemic stroke, caused astrocytic inflammation via the NLRP3 inflammasome and downregulation of SLC1A3(Park et al,2020). Myelin-specific $\mathrm{CD}^{+}$Th1 cells stimulated glutamate release by SLC7A11 in microglia, and SLC7A11 inhibition improved the conditions of EAE mice and decreased T cell infiltration into the CNS(Evonuk et al,2015). Additionally, Slclal ${ }^{+-}$mice have elevated levels of inflammatory cytokines in the brain(Afshari et al,2017), and a Slclal suppressor microRNA (miR-26a) affected the response to IFN- $\beta$ treatment in MS patients(Potenza et al,2018). While peripheral nerve injury resulted in both upregulation of glucocorticoid receptors and downregulation of SLC1A1, 
inhibition of glucocorticoid receptors rescues SLC1A1 expression levels, possibly through the NF-kB signaling pathway(Wang et al,2006). Furthermore, $1,25(\mathrm{OH})_{2} \mathrm{D}_{3}$ regulates both SlclAl and lipopolysaccharide (LPS)-binding protein CD14 in human osteoclasts(Tarroni et al,2012).

Increased human endogenous retrovirus (HERV) gene activity occurs in immunologically activated glia, and HERV-W encoded glycoprotein syncytin is upregulated in glial cells within acute demyelinating lesions of MS patients(Antony et al,2004). SLC1A4 was found to be a receptor of the HERV-W envelope protein syncytin-1, which could induce iNOS via old astrocyte specifically induced substance (OASIS), and OASIS suppressed astrocytic SLC1A4(Antony et al,2007). SLC1A5 was reported to be another syncytin-1 receptor and was highly expressed in human umbilical vein endothelial cells (HUVEC)(Yan et al,2017). Syncytin-1 could be induced by TNF- $\alpha$ via the Wnt/ $\beta$-catenin pathway in squamous cell carcinoma cells 9 (SCC-9), indicating that the interaction of SLC1A5-syncytin-1 may promote cancerendothelial cell fusion(Yan et al,2017).

SLC1A2 is also relevant to other nervous system disorders. The autoantibody NMO-IgG, a biomarker of neuromyelitis optica, targets the aquaporin 4 (AQP4) water channel on astrocytes(Hinson et al,2008). SLC1A2 expression levels vary according to changes in AQP4 expression, suggesting that SLC1A2 might form complexes with AQP4, and thus pathologically produced NMO-IgG might cause excitotoxicity via AQP4 binding(Hinson et al,2008). Upregulation of SLC1A2 by an antibiotic, ceftriaxone, was shown to accompany downregulation of pro-inflammatory cytokines in rats with traumatic brain injury(Wei et al,2012), and in amyotrophic lateral sclerosis, a stearyl-norleucinevasoactive intestinal peptide rescued the levels and function of SLC1A2 via suppression of TNF- $\alpha$ and downregulation of NF- $\mathrm{kB}($ Goursaud et al,2015). SLC1A2 was also found to be reduced in brains of Alzheimer's disease (AD) patients. SLC1A2 deprivation in astrocytes resulted in both innate and adaptive immune function failure, with gene expression pattern changes similar to those caused by inflammation and synaptic function changes in $\mathrm{AD}$ or aged brains, which has been associated with early-onset deficits 
in short-term memory; meanwhile, SLC1A2 deprivation in neurons was associated with late-onset deficits in long-term memory(Sharma et al,2019).

The SLC1A family also plays a key role in chronic pain, and arachidonic acid is a critical regulator of inflammatory pathways that increases pain sensitivity after nerve injury by activating inflammatory pathways and affecting microglia and astrocytes. The expression/activity of the glutamate transporter in the middle of the synaptic cleft leads to a sustained increase in the concentration of glutamate in and/or around the synaptic cleft, ultimately leading to the continued development of neuropathic pain(Gegelashvili and Bjerrum,2019).

\section{SLCs during infection}

Several studies suggested that SLC1A2 participates in viral infections, primarily in the CNS. Inflammatory macrophage activation during human immunodeficiency virus (HIV) infection caused CNS symptoms and was associated with glutamate excitotoxicity. However, macrophages were less affected by compensatory increased SLC1A2 expression and GS inhibition due to a reduction in glutamate transport during HIV replication, supporting a potential replacement of affected astrocytes(Porcheray et al,2006). Astrocyte elevated gene-1 (AEG-1) was found to promote HIV-1-associated neuroinflammation via suppression of SLC1A2 and the NF- $\mathrm{B}$ pathway(Vartak-Sharma et al,2014). During HIV-associated neurocognitive disorders, trace amine receptor 1 (TAAR1) negatively regulated SLC1A2 expression and glutamate uptake, and TAAR1 disruption prevented the decrease in SLC1A2 mediated by methamphetamine, a TAAR1 agonist(Cisneros and Ghorpade,2014). Japanese encephalitis virus (JEV) infection in neurons caused astrogliosis, and elevated SLC1A3 and SLC1A2 expression to detoxify glutamate, and induced other neuroprotective changes, which were nonetheless insufficient to overcome neuronal injuries(Mishra et al,2007). In acute flaccid paralysis caused by the West Nile virus (WNV), the immune response to WNV in the spinal cord influenced astrocytic glutamate reuptake, leading to higher extracellular glutamate and thus, cells without direct virus infection were also damaged by excitotoxicity(Blakely et al,2009). In the early stage of Borna disease virus infections, zebrin II/SLC1A6 
expression was reported to be a marker for subsets of Purkinje cells with different susceptibility to the virus(Williams et al,2007). SLC7A11 was identified as a receptor for Kaposi's sarcoma-associated herpesvirus (KSHV), promoting cell fusion and virion entry of the virus(Kaleeba and Berger,2006). In primary effusion lymphoma (PEL) caused by KSHV, targeting SLC7A11 promoted apoptosis of PEL cells, and inhibitors of SLC7A11 or downstream genes were potential therapeutic targets(Dai et al,2015).

SLCs transporters have also been studied during bacterial infection. Inflammation in astrocytes could weaken gap junctions, and in the short term, hemichannel activity adjacent to Staphylococcus aureusinfected areas were directly correlated with an increased expression of Cx43, Cx30, Panx1, SLC1A3 and SLC1A2(Karpuk et al,2011). During Helicobacter pylori infection, Slc7a2 knockout not only inhibited the innate immune response of mice, but also skewed the adaptive immune response from Th1 to Th2(Barry et al,2011). During Mycobacterium tuberculosis infection, avirulent strains led to higher SLC7A2 expression levels in macrophages than virulent strains, suggesting a role of SLC7A2 in controlling immune response of macrophages towards bacterial infection(Lee et al,2019). Finally, proinflammatory signals and Slc7a5 expression were both upregulated by Shigella flexneri infection in a new model of intestine named human intestinal enteroids (HIEs)(Koestler et al,2019).

The impact of SLCs during parasitic and helminth infections is less known, but BALB-C mice, which are more susceptible to Leishmania major infection, showed higher Slc7a2 expression in macrophages after IFN- $\gamma$ or IL-4 treatment; and increased arginine might favor the growth of Leishmania major(Sans-Fons et al,2013).

\section{SLCs in other chronic or autoimmune diseases}

SLCs have also been implicated in numerous other chronic inflammatory or autoimmunity diseases. Inflammatory bowel disease (IBD) mainly includes two distinct clinical conditions; Crohn's disease (CD) and ulcerative colitis (UC), and is thought to be caused by an abnormally activated immune response to normal luminal flora(Podolsky,2002). Activating transcription factor 4 (ATF4) was downregulated in 
inflamed intestinal mucosa of IBD patients, while Slcla5 transcription was suppressed by ATF4 deficiency in mice, leading to lower glutamine uptake and antimicrobial peptide synthesis in intestinal epithelial cells(Hu et al,2019). During active UC, tissue SLC7A2 and ARG1 expression levels, and arginine concentration were decreased, while NOS2, ARG2 expression were higher(Coburn et al,2016). Dextran sulfate sodium (DSS) induced more severe UC in Slc7a2 knockout mice. Similarly, in an azoxymethane (AOM)-DSS model of colitis-associated carcinogenesis (CAC), Slc7a2 knockout resulted in increased pro-inflammatory cytokines/chemokines and decreased IL-4, CXCL9, and CXCL10, skewing towards pro-tumorigenic M2 activation of macrophages(Coburn et al,2019). UC also reduced chromosome-associated protein D3 (CAP-D3) upregulating SLC7A5/CD98 expression, and system L or mTORC1 inhibition restored the bacterial clearance defects of colon epithelial cells lacking CAPD3(Schuster et al,2015).

Citrobacter rodentium is a widely used mouse model for human intestinal diseases including IBD. Arginine transporters are involved in conditions such as infections and IBD. In mice, Slc7a2 expression is upregulated in colitis tissues after Citrobacter rodentium infection, and Slc7a2 knockout weakened the immune response and attachment of $C$. rodentium to the epithelium(Singh et al,2016). Another study showed that elevated arginine levels in the mouse colon at the peak of $C$. rodentium infection was correlated with downregulation of host Slc7a2 and upregulation of $C$. rodentium virulence gene expression, indicating that the balance between host and pathogen was affected by arginine(MenezesGarcia et al,2020).

SLC1A3 and SLC1A2 are also enriched in the joints of the osteoarthritis (OA) rabbit model, resulting in higher concentrations of glutamate and aspartate(Hascup et al,2016). In addition, in the rat retinal Müller cell line rMC-1 induced by high glucose, lower GS and SLC1A3 levels led to higher glutamate levels, and higher IL-17A production, IL-17 receptor A, GFAP, VEGF expression, indicating involvement of SLC1A3 in diabetic retinopathy, a complication of autoimmune diabetes(Qiu et al,2017). During psoriasis, CD69 in skin $\gamma \delta$ T cells altered aryl hydrocarbon receptor (AhR)-dependent IL-22 secretion and 
skin inflammation via its regulatory effect on surface expression of SLC7A5-CD98, L-tryptophan uptake and tryptophan-derived AhR activators(Cibrian et al,2016). Finally, in the murine lung during asthma, Arg1 deficiency improved the function and adaptive regulation of Slc7al together with Arg2, Nos2, Slc7a7, Ccl2, Ccl11, Tnfa, and Ifny, but failed to relieve airway inflammation(Zhu et al,2021). Slc7al expression was also upregulated in mammary alveolar epithelial cells (AEC) by LPS stimulation in mouse mammary glands(Kobayashi et al,2013).

\section{SLC-targeted therapeutics and conclusion}

Over the past decades, a number of inhibitors targeting SLC1 and SLC7 transporters (Table 2) and many SLC-targeted therapeutics have been developed. However, for SLC1 and SLC7 family transporters only one Riluzole (SLC1A3) has been approved for the treatment of amyotrophic lateral sclerosis(Lin et al,2015). Nonetheless, several preclinical studies suggest SLC-targeted therapeutics against cancer and MS. In breast tumors enriched with cancer stem cells (CSC), targeting SLC7A11 could stimulate immune response and improve chemotherapy sensitivity(Ruiu et al,2019), leading to the development of a viruslike-particle immunotherapeutic approach to target SLC7A11 protein(Bolli et al,2018). Furthermore, SLC7A1 expression was enhanced in a arginine starvation model that mimics an important tumor immune evasion mechanism. Under arginine deprivation SLC7A1 inhibition resulted in arginine uptake and cellular proliferation blockade of $\mathrm{T}$ cells(Werner et al,2016). In addition, since arginine synthesis was blocked and SLC7A1 was the only arginine transporter expressed in chronic lymphocytic leukemia (CLL) cells, SLC7A1 inhibition may represent a promising CLL treatment(Werner et al,2019). Slc7a5 was also overexpressed in T cell malignancies, and its inhibitor JPH203 showed an anti-tumor effect(Rosilio et al,2015).

Several agents have been proposed as potential MS therapies that rescue SLC1A3 and SLC1A2 expression. Matrine, a natural quinolizidine alkaloid, showed beneficial effects on inflammation and demyelination in EAE mice by lowering glutamate and increasing SLC1A3 and SLC1A2 expression and GABA concentrations in the brain(Kan et al,2014). EAE mice treated with the immunosuppressive MS 
medication, fingolimod, exhibited less inflammation mediated by $\mathrm{T}$ cells and macrophages/microglia, less astrocyte activation, and restored SLC1A3, SLC1A2 levels in the inflamed spinal cord, potentially via an indirect mechanism(Lee et al,2017). Similarly, In LPS-stimulated astrocytes, disruption of GluA2, a subunit of glutamate receptor AMPAR, by an interfering peptide rescued the expression levels of SLC1A3, SLC1A2, and relieved the MS symptoms of EAE mice(Lee et al,2018). Besides matrine and fingolimod, we found three agonists of SLC1A2. The first one is LDN-212320, which can increase the level of SLC1A2 protein in astrocytes(Xing et al,2011); the second is GPI-1046, which is an antibioticfree immunoavidin ligand that reduces ethanol intake by upregulating SLC1A2 in the PFC and NAc cores(Sari and Sreemantula,2012); the last one is GT 949, which enhances glutamate transport with an EC50 of $0.26 \pm 0.03 \mathrm{nM}$. GT 949 also demonstrates selectivity to SLC1A2 and has no effect on glutamate activity mediated by SLC1A3 or SLC1A1(Kortagere et al,2018).

In obese patients, a population of $\mathrm{T}$ cells called mucosal-associated invariant $\mathrm{T}$ (MAIT) cells were dysregulated and showed defective glycolytic metabolism and amino acid transport by SLC7A5 necessary for downstream mTORC1 signaling(O'Brien et al,2019). SLC7A5 inhibition controlled the proliferation of $\gamma \delta \mathrm{T}$ cells, IL-17 secretion of $\mathrm{CD}^{+} \mathrm{T}$ cells, and the inflammatory response of both cells via the IL-23 and IL-1 $\beta$-induced PI3K/AKT/mTOR pathway in psoriasis(Cibrian et al,2020). And for neurological disease, astrocytes have high transport capacity and affinity for the SLC7A5 substrate [14C]-L-leucine, followed by neurons and microglia, hence such prodrug can use Lat1 for cellular uptake with much higher activity than one of its parent drugs(Huttunen et al,2019).

Currently, there are no reports on the gene polymorphisms (SNPS) of SLC1 and SLC7 family members directly in inflammatory and autoimmune diseases. The diseases related to SLC1 family SNPs were mainly obsessive-compulsive disorder, schizophrenia, epilepsy, essential tremor, stress depression and multiple system atrophy(Gadow et al,2010, Ghosh et al,2020, Jimenez-Jimenez et al,2015, Ritter et al,2016, Soma et al,2008, Wendland et al,2009, Yu et al,2018). The SLC7 family is mostly associated 
with susceptibility to leprosy, multiple myeloma, schizophrenia and tuberculosis(Cai et al,2018, Poi et al,2019, Wang et al,2020b, Wang et al,2018).

Taken together, SLCs of amino acids, especially SLC1 family members as glutamate transporters and SLC7 members as arginine transporters, play important roles in various conditions involving inflammation and immune responses, such as MS, IBD, viral infections, tumor immunotherapies, and chronic intestinal inflammation via modulating the function of astrocytes, macrophages, and $\mathrm{T}$ cells. Further studies should focus on determining the specific mechanism of these SLCs in regulating immune functions and course of diseases, developing specific inhibitors as potential therapy for these diseases, or characterizing the numerous SLCs that still remain to be studied. 


\section{Acknowledgment}

This review tributes to Dr. Kathleen M. Giacomini, a pioneer and beloved mentor in transporter pharmacogenomics and biology. Both Dr. Ligong Chen and Ms. Qi Luo are trained in Dr. Kathy's lab as postdoc and exchange student, respectively. Kathy leads Ligong to the field of transporter pharmacology and shows the great potential and fantasy of transporter in physiology and drug development. Since May 2013, Ligong has been an independent Princinal Investigtor in Tsinghua University in Beijing, China. 


\section{Authorship Contributions}

Participated in research design: Ligong Chen.

Performed data analysis: Linlin Sheng and Qi Luo.

Wrote or contributed to the writing of the manuscript: Ligong Chen, Linlin Sheng and Qi Luo. 


\section{Reference}

Abrahamsen B, Schneider N, Erichsen MN, Huynh TH, Fahlke C, Bunch L, Jensen AA (2013) Allosteric modulation of an excitatory amino acid transporter: the subtype-selective inhibitor UCPH-101 exerts sustained inhibition of EAAT1 through an intramonomeric site in the trimerization domain. $J$ Neurosci 33 : 1068-1087.

Afshari P, Yao WD, Middleton FA (2017) Reduced Slc1a1 expression is associated with neuroinflammation and impaired sensorimotor gating and cognitive performance in mice: Implications for schizophrenia. Plos One 12.

Albertini G, Deneyer L, Ottestad-Hansen S, Zhou Y, Ates G, Walrave L, Demuyser T, Bentea E, Sato H, De Bundel D, Danbolt NC, Massie A, Smolders I (2018) Genetic deletion of xCT attenuates peripheral and central inflammation and mitigates LPS-induced sickness and depressive-like behavior in mice. Glia 66: $1845-1861$.

Antony JM, Ellestad KK, Hammond R, Imaizumi K, Mallet F, Warren KG, Power C (2007) The human endogenous retrovirus envelope glycoprotein, syncytin-1, regulates neuroinflammation and its receptor expression in multiple sclerosis: a role for endoplasmic reticulum chaperones in astrocytes. $J$ Immunol 179: $1210-1224$.

Antony JM, van Marle G, Opii W, Butterfield DA, Mallet F, Yong VW, Wallace JL, Deacon RM, Warren K, Power C (2004) Human endogenous retrovirus glycoprotein-mediated induction of redox reactants causes oligodendrocyte death and demyelination. Nat Neurosci 7: 1088-1095.

Arensman MD, Yang XS, Leahy DM, Toral-Barza L, Mileski M, Rosfjord EC, Wang F, Deng S, Myers JS, Abraham RT, Eng CH (2019) Cystine-glutamate antiporter xCT deficiency suppresses tumor growth while preserving antitumor immunity. Proc Natl Acad Sci U S A 116: 9533-9542.

Arriza JL, Fairman WA, Wadiche JI, Murdoch GH, Kavanaugh MP, Amara SG (1994) Functional comparisons of three glutamate transporter subtypes cloned from human motor cortex. J Neurosci 14: 5559-5569.

Barilli A, Rotoli BM, Visigalli R, Bussolati O, Gazzola GC, Dall'Asta V (2011) Arginine transport in 
human monocytic leukemia THP-1 cells during macrophage differentiation. J Leukoc Biol 90: 293-303.

Barilli A, Rotoli BM, Visigalli R, Bussolati O, Gazzola GC, Gatti R, Dionisi-Vici C, Martinelli D, Goffredo BM, Font-Llitjos M, Mariani F, Luisetti M, Dall'Asta V (2012) Impaired phagocytosis in macrophages from patients affected by lysinuric protein intolerance. Mol Genet Metab 105: 585-589.

Barry DP, Asim M, Scull BP, Piazuelo MB, de Sablet T, Lewis ND, Coburn LA, Singh K, Ellies LG, Gobert AP, Chaturvedi R, Wilson KT (2011) Cationic amino acid transporter 2 enhances innate immunity during Helicobacter pylori infection. PLoS One 6: e29046.

Blakely PK, Kleinschmidt-DeMasters BK, Tyler KL, Irani DN (2009) Disrupted glutamate transporter expression in the spinal cord with acute flaccid paralysis caused by West Nile virus infection. $J$ Neuropathol Exp Neurol 68: 1061-1072.

Bolli E, O'Rourke JP, Conti L, Lanzardo S, Rolih V, Christen JM, Barutello G, Forni M, Pericle F, Cavallo F (2018) A Virus-Like-Particle immunotherapy targeting Epitope-Specific anti-xCT expressed on cancer stem cell inhibits the progression of metastatic cancer in vivo. Oncoimmunology 7: e1408746.

Bozkus CC, Elzey BD, Crist SA, Ellies LG, Ratliff TL (2015) Expression of Cationic Amino Acid Transporter 2 Is Required for Myeloid-Derived Suppressor Cell-Mediated Control of T Cell Immunity. Journal of Immunology 195: 5237-5250.

Cady RJ, Denson JE, Durham PL (2013) Inclusion of cocoa as a dietary supplement represses expression of inflammatory proteins in spinal trigeminal nucleus in response to chronic trigeminal nerve stimulation. Mol Nutr Food Res 57: 996-1006.

Cai Z, Villumsen TM, Asp T, Guldbrandtsen B, Sahana G, Lund MS (2018) SNP markers associated with body size and pelt length in American mink (Neovison vison). BMC Genet 19: 103.

Chen CC, Lee JJ, Tsai PS, Lu YT, Huang CL, Huang CJ (2006) Platonin attenuates LPS-induced CAT-2 and CAT-2B induction in stimulated murine macrophages. Acta Anaesthesiol Scand 50: 604-612.

Chen L, Chen XW, Huang X, Song BL, Wang Y, Wang Y (2019) Regulation of glucose and lipid metabolism in health and disease. Sci China Life Sci 62: 1420-1458.

Cibrian D, Castillo-Gonzalez R, Fernandez-Gallego N, de la Fuente H, Jorge I, Saiz ML, Punzon C, 
Ramirez-Huesca M, Vicente-Manzanares M, Fresno M, Dauden E, Fraga-Fernandez J, Vazquez J, Aragones J, Sanchez-Madrid F (2020) Targeting L-type amino acid transporter 1 in innate and adaptive T cells efficiently controls skin inflammation. J Allergy Clin Immunol 145: 199-214 e111.

Cibrian D, Saiz ML, de la Fuente H, Sanchez-Diaz R, Moreno-Gonzalo O, Jorge I, Ferrarini A, Vazquez J, Punzon C, Fresno M, Vicente-Manzanares M, Dauden E, Fernandez-Salguero PM, Martin P, SanchezMadrid F (2016) CD69 controls the uptake of L-tryptophan through LAT1-CD98 and AhR-dependent secretion of IL-22 in psoriasis (vol 17, pg 985, 2016). Nature Immunology 17: 1235-1235.

Cisneros IE, Ghorpade A (2014) Methamphetamine and HIV-1-induced neurotoxicity: role of trace amine associated receptor 1 cAMP signaling in astrocytes. Neuropharmacology 85: 499-507.

Coburn LA, Horst SN, Allaman MM, Brown CT, Williams CS, Hodges ME, Druce JP, Beaulieu DB, Schwartz DA, Wilson KT (2016) 1-Arginine Availability and Metabolism Is Altered in Ulcerative Colitis. Inflamm Bowel Dis 22: 1847-1858.

Coburn LA, Singh K, Asim M, Barry DP, Allaman MM, Al-Greene NT, Hardbower DM, Polosukhina D, Williams CS, Delgado AG, Piazuelo MB, Washington MK, Gobert AP, Wilson KT (2019) Loss of solute carrier family 7 member 2 exacerbates inflammation-associated colon tumorigenesis. Oncogene 38: 10671079.

Compston A, Coles A (2008) Multiple sclerosis. Lancet 372: 1502-1517.

Corti A, Dominici S, Piaggi S, Belcastro E, Chiu M, Taurino G, Pacini S, Bussolati O, Pompella A (2019) gamma-Glutamyltransferase enzyme activity of cancer cells modulates L-gamma-glutamyl-p-nitroanilide (GPNA) cytotoxicity. Sci Rep 9: 891.

Costello DA, Lynch MA (2013) Toll-like receptor 3 activation modulates hippocampal network excitability, via glial production of interferon-beta. Hippocampus 23: 696-707.

Dai L, Cao Y, Chen Y, Kaleeba JA, Zabaleta J, Qin Z (2015) Genomic analysis of xCT-mediated regulatory network: Identification of novel targets against AIDS-associated lymphoma. Oncotarget 6: $12710-12722$.

D'Elia M, Patenaude J, Dupras C, Bernier J (2009) Burn injury induces the expression of 
cystine/glutamate transporter $(\mathrm{x}(\mathrm{c})(-))$ in mouse T cells. Immunol Lett 125: 137-144.

Deuschl G, Beghi E, Fazekas F, Varga T, Christoforidi KA, Sipido E, Bassetti CL, Vos T, Feigin VL (2020) The burden of neurological diseases in Europe: an analysis for the Global Burden of Disease Study 2017. Lancet Public Health 5: e551-e567.

Eliasof S, McIlvain HB, Petroski RE, Foster AC, Dunlop J (2001) Pharmacological characterization of threo-3-methylglutamic acid with excitatory amino acid transporters in native and recombinant systems. $J$ Neurochem 77: 550-557.

Evonuk KS, Baker BJ, Doyle RE, Moseley CE, Sestero CM, Johnston BP, De Sarno P, Tang A, Gembitsky I, Hewett SJ, Weaver CT, Raman C, DeSilva TM (2015) Inhibition of System Xc(-) Transporter Attenuates Autoimmune Inflammatory Demyelination. J Immunol 195: 450-463.

Fotiadis D, Kanai Y, Palacin M (2013) The SLC3 and SLC7 families of amino acid transporters. Mol Aspects Med 34: 139-158.

Fraga S, Serrao MP, Soares-da-Silva P (2002) L-type amino acid transporters in two intestinal epithelial cell lines function as exchangers with neutral amino acids. J Nutr 132: 733-738.

Furman D, Campisi J, Verdin E, Carrera-Bastos P, Targ S, Franceschi C, Ferrucci L, Gilroy DW, Fasano A, Miller GW, Miller AH, Mantovani A, Weyand CM, Barzilai N, Goronzy JJ, Rando TA, Effros RB, Lucia A, Kleinstreuer N, Slavich GM (2019) Chronic inflammation in the etiology of disease across the life span. Nat Med 25: 1822-1832.

Gadow KD, Roohi J, DeVincent CJ, Kirsch S, Hatchwell E (2010) Glutamate transporter gene (SLC1A1) single nucleotide polymorphism (rs301430) and repetitive behaviors and anxiety in children with autism spectrum disorder. J Autism Dev Disord 40: 1139-1145.

Gegelashvili G, Bjerrum OJ (2019) Glutamate transport system as a key constituent of glutamosome: Molecular pathology and pharmacological modulation in chronic pain. Neuropharmacology 161: 107623. Ghosh M, Ali A, Joshi S, Srivastava AS, Tapadia MG (2020) SLC1A3 C3590T but not BDNF G196A is a predisposition factor for stress as well as depression, in an adolescent eastern Indian population. $B M C$ Med Genet 21: 53. 
Goursaud S, Schafer S, Dumont AO, Vergouts M, Gallo A, Desmet N, Deumens R, Hermans E (2015) The anti-inflammatory peptide stearyl-norleucine-VIP delays disease onset and extends survival in a rat model of inherited amyotrophic lateral sclerosis. Exp Neurol 263: 91-101.

Hascup ER, Wang F, Kopchick JJ, Bartke A (2016) Inflammatory and Glutamatergic Homeostasis Are Involved in Successful Aging. J Gerontol A Biol Sci Med Sci 71: 281-289.

Hashimoto M, Girardi E, Eichner R, Superti-Furga G (2018) Detection of Chemical Engagement of Solute Carrier Proteins by a Cellular Thermal Shift Assay. ACS Chem Biol 13: 1480-1486.

Hayashi K, Ouchi M, Endou H, Anzai N (2016) HOXB9 acts as a negative regulator of activated human T cells in response to amino acid deficiency. Immunol Cell Biol 94: 612-617.

Haym I, Huynh TH, Hansen SW, Pedersen MH, Ruiz JA, Erichsen MN, Gynther M, Bjorn-Yoshimoto WE, Abrahamsen B, Bastlund JF, Bundgaard C, Eriksen AL, Jensen AA, Bunch L (2016) Bioavailability Studies and in vitro Profiling of the Selective Excitatory Amino Acid Transporter Subtype 1 (EAAT1) Inhibitor UCPH-102. ChemMedChem 11: 403-419.

He W, Tao W, Zhang F, Jie Q, He Y, Zhu W, Tan J, Shen W, Li L, Yang Y, Cheng H, Sun D (2020) Lobetyolin induces apoptosis of colon cancer cells by inhibiting glutamine metabolism. J Cell Mol Med 24: 3359-3369.

Hinson SR, Roemer SF, Lucchinetti CF, Fryer JP, Kryzer TJ, Chamberlain JL, Howe CL, Pittock SJ, Lennon VA (2008) Aquaporin-4-binding autoantibodies in patients with neuromyelitis optica impair glutamate transport by down-regulating EAAT2. J Exp Med 205: 2473-2481.

Hu X, Deng J, Yu T, Chen S, Ge Y, Zhou Z, Guo Y, Ying H, Zhai Q, Chen Y, Yuan F, Niu Y, Shu W, Chen H, Ma C, Liu Z, Guo F (2019) ATF4 Deficiency Promotes Intestinal Inflammation in Mice by Reducing Uptake of Glutamine and Expression of Antimicrobial Peptides. Gastroenterology 156: 1098-1111.

Huttunen J, Peltokangas S, Gynther M, Natunen T, Hiltunen M, Auriola S, Ruponen M, Vellonen KS, Huttunen KM (2019) L-Type Amino Acid Transporter 1 (LAT1/Lat1)-Utilizing Prodrugs Can Improve the Delivery of Drugs into Neurons, Astrocytes and Microglia. Sci Rep-Uk 9.

Huttunen KM, Gynther M, Huttunen J, Puris E, Spicer JA, Denny WA (2016) A Selective and Slowly 
Reversible Inhibitor of 1-Type Amino Acid Transporter 1 (LAT1) Potentiates Antiproliferative Drug Efficacy in Cancer Cells. J Med Chem 59: 5740-5751.

Jensen H, Potempa M, Gotthardt D, Lanier LL (2017) Cutting Edge: IL-2-Induced Expression of the Amino Acid Transporters SLC1A5 and CD98 Is a Prerequisite for NKG2D-Mediated Activation of Human NK Cells. J Immunol 199: 1967-1972.

Ji X, Yang X, Wang N, Kang M, Wang Y, Rong L, Fang Y, Xue Y (2018) Function of SLC7A7 in T-Cell Acute Lymphoblastic Leukemia. Cell Physiol Biochem 48: 731-740.

Jiang S, Yan W, Wang SE, Baltimore D (2018) Let-7 Suppresses B Cell Activation through Restricting the Availability of Necessary Nutrients. Cell Metab 27: 393-403 e394.

Jimenez-Jimenez FJ, Alonso-Navarro H, Garcia-Martin E, Agundez JA (2015) SLC1A2 rs3794087 variant and risk for essential tremor: a systematic review and meta-analysis. Pharmacogenet Genomics 25: 564-568.

Kaleeba JA, Berger EA (2006) Kaposi's sarcoma-associated herpesvirus fusion-entry receptor: cystine transporter xCT. Science 311: 1921-1924.

Kan QC, Zhang S, Xu YM, Zhang GX, Zhu L (2014) Matrine regulates glutamate-related excitotoxic factors in experimental autoimmune encephalomyelitis. Neurosci Lett 560: 92-97.

Kanai Y, Clemencon B, Simonin A, Leuenberger M, Lochner M, Weisstanner M, Hediger MA (2013) The SLC1 high-affinity glutamate and neutral amino acid transporter family. Mol Aspects Med 34: 108-120.

Kandasamy RK, Vladimer GI, Snijder B, Muller AC, Rebsamen M, Bigenzahn JW, Moskovskich A, Sabler M, Stefanovic A, Scorzoni S, Bruckner M, Penz T, Cleary C, Kralovics R, Colinge J, Bennett KL, Superti-Furga G (2016) A time-resolved molecular map of the macrophage response to VSV infection. NPJ Syst Biol Appl 2: 16027.

Karpuk N, Burkovetskaya M, Fritz T, Angle A, Kielian T (2011) Neuroinflammation leads to regiondependent alterations in astrocyte gap junction communication and hemichannel activity. $J$ Neurosci 31 : 414-425.

Kastan N, Gnedeva K, Alisch T, Petelski AA, Huggins DJ, Chiaravalli J, Aharanov A, Shakked A, Tzahor 
E, Nagiel A, Segil N, Hudspeth AJ (2021) Small-molecule inhibition of Lats kinases may promote Yapdependent proliferation in postmitotic mammalian tissues. Nat Commun 12.

Kim DK, Kanai Y, Choi HW, Tangtrongsup S, Chairoungdua A, Babu E, Tachampa K, Anzai N, Iribe Y, Endou H (2002) Characterization of the system L amino acid transporter in T24 human bladder carcinoma cells. Biochim Biophys Acta 1565: 112-121.

Knyazev EN, Mal'tseva DV, Zacharyants AA, Zakharova GS, Zhidkova OV, Poloznikov AA (2018) TNFalpha-Induced Expression of Transport Protein Genes in HUVEC Cells Is Associated with Enhanced Expression of Transcription Factor Genes RELB and NFKB2 of the Non-Canonical NF-kappaB Pathway. Bull Exp Biol Med 164: 757-761.

Kobayashi K, Oyama S, Uejyo T, Kuki C, Rahman MM, Kumura H (2013) Underlying mechanisms involved in the decrease of milk secretion during Escherichia coli endotoxin induced mastitis in lactating mice. Vet Res 44: 119.

Kobayashi S, Hamashima S, Homma T, Sato M, Kusumi R, Bannai S, Fujii J, Sato H (2018) Cystine/glutamate transporter, system xc(-), is involved in nitric oxide production in mouse peritoneal macrophages. Nitric Oxide 78: 32-40.

Koestler BJ, Ward CM, Fisher CR, Rajan A, Maresso AW, Payne SM (2019) Human Intestinal Enteroids as a Model System of Shigella Pathogenesis. Infect Immun 87.

Kortagere S, Mortensen OV, Xia J, Lester W, Fang Y, Srikanth Y, Salvino JM, Fontana ACK (2018) Identification of Novel Allosteric Modulators of Glutamate Transporter EAAT2. ACS Chem Neurosci 9: $522-534$.

Kostic M, Zivkovic N, Cvetanovic A, Stojanovic I, Colic M (2017) IL-17 signalling in astrocytes promotes glutamate excitotoxicity: Indications for the link between inflammatory and neurodegenerative events in multiple sclerosis. Mult Scler Relat Disord 11: 12-17.

Kurko J, Vaha-Makila M, Tringham M, Tanner L, Paavanen-Huhtala S, Saarinen M, Nanto-Salonen K, Simell O, Niinikoski H, Mykkanen J (2015) Dysfunction in macrophage toll-like receptor signaling caused by an inborn error of cationic amino acid transport. Mol Immunol 67: 416-425. 
Le TM, Takarada-Iemata M, Ta HM, Roboon J, Ishii H, Tamatani T, Kitao Y, Hattori T, Hori O (2018) Ndrg2 deficiency ameliorates neurodegeneration in experimental autoimmune encephalomyelitis. $J$ Neurochem 145: 139-153.

Lee DH, Seubert S, Huhn K, Brecht L, Rotger C, Waschbisch A, Schlachetzki J, Klausmeyer A, Melms A, Wiese S, Winkler J, Linker RA (2017) Fingolimod effects in neuroinflammation: Regulation of astroglial glutamate transporters? PLoS One 12: e0171552.

Lee FHF, Zhang H, Jiang A, Zai CC, Liu F (2018) Specific Alterations in Astrocyte Properties via the GluA2-GAPDH Complex Associated with Multiple Sclerosis. Sci Rep 8: 12856.

Lee J, Lee SG, Kim KK, Lim YJ, Choi JA, Cho SN, Park C, Song CH (2019) Characterisation of genes differentially expressed in macrophages by virulent and attenuated Mycobacterium tuberculosis through RNA-Seq analysis. Sci Rep 9: 4027.

Liang Y, Li S, Chen L (2015) The physiological role of drug transporters. Protein Cell 6: 334-350.

Lin L, Yee SW, Kim RB, Giacomini KM (2015) SLC transporters as therapeutic targets: emerging opportunities. Nat Rev Drug Discov 14: 543-560.

Loftus RM, Assmann N, Kedia-Mehta N, O'Brien KL, Garcia A, Gillespie C, Hukelmann JL, Oefner PJ, Lamond AI, Gardiner CM, Dettmer K, Cantrell DA, Sinclair LV, Finlay DK (2018) Amino aciddependent cMyc expression is essential for NK cell metabolic and functional responses in mice. Nat Commun 9.

Ma H, Wu J, Zhou M, Wu J, Wu Z, Lin L, Huang N, Liao W, Sun L (2021) Inhibition of Glutamine Uptake Improves the Efficacy of Cetuximab on Gastric Cancer. Integr Cancer Ther 20: 15347354211045349 .

Ma H, Wu Z, Peng J, Li Y, Huang H, Liao Y, Zhou M, Sun L, Huang N, Shi M, Bin J, Liao Y, Rao J, Wang L, Liao W (2018) Inhibition of SLC1A5 sensitizes colorectal cancer to cetuximab. Int J Cancer 142: $2578-2588$.

Mak TW, Grusdat M, Duncan GS, Dostert C, Nonnenmacher Y, Cox M, Binsfeld C, Hao Z, Brustle A, Itsumi M, Jager C, Chen Y, Pinkenburg O, Camara B, Ollert M, Bindslev-Jensen C, Vasiliou V, Gorrini C, 
Lang PA, Lohoff M, Harris IS, Hiller K, Brenner D (2017) Glutathione Primes T Cell Metabolism for Inflammation. Immunity 46: 1089-1090.

Marchingo JM, Sinclair LV, Howden AJ, Cantrell DA (2020) Quantitative analysis of how Myc controls T cell proteomes and metabolic pathways during T cell activation. Elife 9.

Masle-Farquhar E, Broer A, Yabas M, Enders A, Broer S (2017) ASCT2 (SLC1A5)-Deficient Mice Have Normal B-Cell Development, Proliferation, and Antibody Production. Front Immunol 8: 549.

McCord N, Ayuk P, McMahon M, Boyd RCA, Sargent I, Redman C (2006) System y(+) arginine transport and NO production in peripheral blood mononuclear cells in pregnancy and preeclampsia. Hypertension 47: 109-115.

Menezes-Garcia Z, Kumar A, Zhu W, Winter SE, Sperandio V (2020) 1-Arginine sensing regulates virulence gene expression and disease progression in enteric pathogens. Proc Natl Acad Sci U S A 117: $12387-12393$.

Mishra MK, Koli P, Bhowmick S, Basu A (2007) Neuroprotection conferred by astrocytes is insufficient to protect animals from succumbing to Japanese encephalitis. Neurochem Int 50: 764-773.

Nakaya M, Xiao Y, Zhou X, Chang JH, Chang M, Cheng X, Blonska M, Lin X, Sun SC (2014) Inflammatory $\mathrm{T}$ cell responses rely on amino acid transporter ASCT2 facilitation of glutamine uptake and mTORC1 kinase activation. Immunity 40: 692-705.

O'Brien A, Loftus RM, Pisarska MM, Tobin LM, Bergin R, Wood NAW, Foley C, Mat A, Tinley FC, Bannan C, Sommerville G, Veerapen N, Besra GS, Sinclair LV, Moynagh PN, Lynch L, Finlay DK, O'Shea D, Hogan AE (2019) Obesity Reduces mTORC1 Activity in Mucosal-Associated Invariant T Cells, Driving Defective Metabolic and Functional Responses. J Immunol 202: 3404-3411.

Oda K, Hosoda N, Endo H, Saito K, Tsujihara K, Yamamura M, Sakata T, Anzai N, Wempe MF, Kanai Y, Endou H (2010) 1-Type amino acid transporter 1 inhibitors inhibit tumor cell growth. Cancer Sci 101: 173-179.

Pampliega O, Domercq M, Soria FN, Villoslada P, Rodriguez-Antiguedad A, Matute C (2011) Increased expression of cystine/glutamate antiporter in multiple sclerosis. J Neuroinflammation 8: 63. 
Pan H, Xu LH, Huang MY, Zha QB, Zhao GX, Hou XF, Shi ZJ, Lin QR, Ouyang DY, He XH (2015) Piperine metabolically regulates peritoneal resident macrophages to potentiate their functions against bacterial infection. Oncotarget 6: 32468-32483.

Park JH, Choi JY, Jo C, Koh YH (2020) Involvement of ADAM10 in acrolein-induced astrocytic inflammation. Toxicol Lett 318: 44-49.

Pedraz-Cuesta E, Christensen S, Jensen AA, Jensen NF, Bunch L, Romer MU, Brunner N, Stenvang J, Pedersen SF (2015) The glutamate transport inhibitor DL-Threo-beta-Benzyloxyaspartic acid (DL-TBOA) differentially affects SN38- and oxaliplatin-induced death of drug-resistant colorectal cancer cells. BMC Cancer 15: 411.

Pfau JC, Seib T, Overocker JJ, Roe J, Ferro AS (2012) Functional expression of system x(c)- is upregulated by asbestos but not crystalline silica in murine macrophages. Inhal Toxicol 24: 476-485.

Pitt D, Werner P, Raine CS (2000) Glutamate excitotoxicity in a model of multiple sclerosis. Nat Med 6: $67-70$.

Podolsky DK (2002) Inflammatory bowel disease. N Engl J Med 347: 417-429.

Poi MJ, Li J, Johnson JA, Cho YK, Sborov DW, Phelps MA, Hofmeister CC (2019) A Single Nucleotide Polymorphism in SLC7A5 Was Associated With Clinical Response in Multiple Myeloma Patients. Anticancer Res 39: 67-72.

Porcheray F, Leone C, Samah B, Rimaniol AC, Dereuddre-Bosquet N, Gras G (2006) Glutamate metabolism in HIV-infected macrophages: implications for the CNS. Am J Physiol Cell Physiol 291: C618-626.

Potenza N, Mosca N, Mondola P, Damiano S, Russo A, De Felice B (2018) Human miR-26a-5p regulates the glutamate transporter SLC1A1 (EAAT3) expression. Relevance in multiple sclerosis. Biochim Biophys Acta Mol Basis Dis 1864: 317-323.

Qiu AW, Liu QH, Wang JL (2017) Blocking IL-17A Alleviates Diabetic Retinopathy in Rodents. Cell Physiol Biochem 41: 960-972.

Ritter AC, Kammerer CM, Brooks MM, Conley YP, Wagner AK (2016) Genetic variation in neuronal 
glutamate transport genes and associations with posttraumatic seizure. Epilepsia 57: 984-993.

Rosilio C, Nebout M, Imbert V, Griessinger E, Neffati Z, Benadiba J, Hagenbeek T, Spits H, Reverso J, Ambrosetti D, Michiels JF, Bailly-Maitre B, Endou H, Wempe MF, Peyron JF (2015) L-type amino-acid transporter 1 (LAT1): a therapeutic target supporting growth and survival of T-cell lymphoblastic lymphoma/T-cell acute lymphoblastic leukemia. Leukemia 29: 1253-1266.

Rothenberg ME, Doepker MP, Lewkowich IP, Chiaramonte MG, Stringer KF, Finkelman FD, MacLeod CL, Ellies LG, Zimmermann N (2006) Cationic amino acid transporter 2 regulates inflammatory homeostasis in the lung. Proc Natl Acad Sci U S A 103: 14895-14900.

Rotoli BM, Barilli A, Visigalli R, Ingoglia F, Milioli M, Di Lascia M, Riccardi B, Puccini P, Dall'Asta V (2018) Downregulation of SLC7A7 Triggers an Inflammatory Phenotype in Human Macrophages and Airway Epithelial Cells. Front Immunol 9: 508.

Ruiu R, Rolih V, Bolli E, Barutello G, Riccardo F, Quaglino E, Merighi IF, Pericle F, Donofrio G, Cavallo F, Conti L (2019) Fighting breast cancer stem cells through the immune-targeting of the xCT cystineglutamate antiporter. Cancer Immunol Immun 68: 131-141.

Sans-Fons MG, Yeramian A, Pereira-Lopes S, Santamaria-Babi LF, Modolell M, Lloberas J, Celada A (2013) Arginine transport is impaired in C57B1/6 mouse macrophages as a result of a deletion in the promoter of Slc7a2 (CAT2), and susceptibility to Leishmania infection is reduced. J Infect Dis 207: 16841693.

Sari Y, Sreemantula SN (2012) Neuroimmunophilin GPI-1046 reduces ethanol consumption in part through activation of GLT1 in alcohol-preferring rats. Neuroscience 227: 327-335.

Schulte ML, Fu A, Zhao P, Li J, Geng L, Smith ST, Kondo J, Coffey RJ, Johnson MO, Rathmell JC, Sharick JT, Skala MC, Smith JA, Berlin J, Washington MK, Nickels ML, Manning HC (2018) Pharmacological blockade of ASCT2-dependent glutamine transport leads to antitumor efficacy in preclinical models. Nat Med 24: 194-202.

Schuster AT, Homer CR, Kemp JR, Nickerson KP, Deutschman E, Kim Y, West G, Sadler T, Stylianou E, Krokowski D, Hatzoglou M, de la Motte C, Rubin BP, Fiocchi C, McDonald C, Longworth MS (2015) 
Chromosome-associated protein D3 promotes bacterial clearance in human intestinal epithelial cells by repressing expression of amino acid transporters. Gastroenterology 148: 1405-1416 e1403.

Sharma A, Kazim SF, Larson CS, Ramakrishnan A, Gray JD, McEwen BS, Rosenberg PA, Shen L, Pereira AC (2019) Divergent roles of astrocytic versus neuronal EAAT2 deficiency on cognition and overlap with aging and Alzheimer's molecular signatures. Proc Natl Acad Sci U S A 116: 21800-21811.

Shimamoto K, Lebrun B, Yasuda-Kamatani Y, Sakaitani M, Shigeri Y, Yumoto N, Nakajima T (1998) DLthreo-beta-benzyloxyaspartate, a potent blocker of excitatory amino acid transporters. Mol Pharmacol 53: 195-201.

Simmons DA, Knowles JK, Belichenko NP, Banerjee G, Finkle C, Massa SM, Longo FM (2014) A small molecule p75NTR ligand, LM11A-31, reverses cholinergic neurite dystrophy in Alzheimer's disease mouse models with mid- to late-stage disease progression. PLoS One 9: e102136.

Sinclair LV, Rolf J, Emslie E, Shi YB, Taylor PM, Cantrell DA (2013) Control of amino-acid transport by antigen receptors coordinates the metabolic reprogramming essential for $\mathrm{T}$ cell differentiation. Nat Immunol 14: 500-508.

Singh K, Al-Greene NT, Verriere TG, Coburn LA, Asim M, Barry DP, Allaman MM, Hardbower DM, Delgado AG, Piazuelo MB, Vallance BA, Gobert AP, Wilson KT (2016) The L-Arginine Transporter Solute Carrier Family 7 Member 2 Mediates the Immunopathogenesis of Attaching and Effacing Bacteria. PLoS Pathog 12: e1005984.

Soma H, Yabe I, Takei A, Fujiki N, Yanagihara T, Sasaki H (2008) Associations between multiple system atrophy and polymorphisms of SLC1A4, SQSTM1, and EIF4EBP1 genes. Mov Disord 23: 1161-1167.

Song W, Li D, Tao L, Luo Q, Chen L (2020) Solute carrier transporters: the metabolic gatekeepers of immune cells. Acta Pharm Sin B 10: 61-78.

Sospedra M, Martin R (2005) Immunology of multiple sclerosis. Annu Rev Immunol 23: 683-747.

Takaki J, Fujimori K, Miura M, Suzuki T, Sekino Y, Sato K (2012) L-glutamate released from activated microglia downregulates astrocytic L-glutamate transporter expression in neuroinflammation: the 'collusion' hypothesis for increased extracellular L-glutamate concentration in neuroinflammation. $J$ 
Neuroinflammation 9: 275.

Tao K, Cai Q, Zhang X, Zhu L, Liu Z, Li F, Wang Q, Liu L, Feng D (2020) Astrocytic histone deacetylase 2 facilitates delayed depression and memory impairment after subarachnoid hemorrhage by negatively regulating glutamate transporter-1. Ann Transl Med 8: 691 .

Tarroni P, Villa I, Mrak E, Zolezzi F, Mattioli M, Gattuso C, Rubinacci A (2012) Microarray analysis of 1,25(OH)(2)D(3) regulated gene expression in human primary osteoblasts. J Cell Biochem 113: 640-649.

Vallejo-Illarramendi A, Domercq M, Perez-Cerda F, Ravid R, Matute C (2006) Increased expression and function of glutamate transporters in multiple sclerosis. Neurobiol Dis 21: 154-164.

Vartak-Sharma N, Gelman BB, Joshi C, Borgamann K, Ghorpade A (2014) Astrocyte elevated gene-1 is a novel modulator of HIV-1-associated neuroinflammation via regulation of nuclear factor-kappaB signaling and excitatory amino acid transporter-2 repression. J Biol Chem 289: 19599-19612.

Vercellino M, Merola A, Piacentino C, Votta B, Capello E, Mancardi GL, Mutani R, Giordana MT, Cavalla P (2007) Altered glutamate reuptake in relapsing-remitting and secondary progressive multiple sclerosis cortex: correlation with microglia infiltration, demyelination, and neuronal and synaptic damage. J Neuropathol Exp Neurol 66: 732-739.

Visigalli R, Bussolati O, Sala R, Barilli A, Rotoli BM, Parolari A, Alamanni F, Gazzola GC, Dall'Asta V (2004) The stimulation of arginine transport by TNFalpha in human endothelial cells depends on NFkappaB activation. Biochim Biophys Acta 1664: 45-52.

Wang G, Shen G, Jiang X, Chen Z, Yin T (2020a) Assessment of para-inflammation in a wound healing model. Exp Ther Med 20: 655-661.

Wang L, Wang FS, Gershwin ME (2015) Human autoimmune diseases: a comprehensive update. J Intern Med 278: 369-395.

Wang SX, Lim G, Yang LL, Sung BK, Mao JR (2006) Downregulation of spinal glutamate transporter EAAC1 following nerve injury is regulated by central glucocorticoid receptors in rats. Pain 120: 78-85.

Wang W, Cai Y, Deng G, Yang Q, Tang P, Wu M, Yu Z, Yang F, Chen J, Werz O, Chen X (2020b) AllelicSpecific Regulation of xCT Expression Increases Susceptibility to Tuberculosis by Modulating 
microRNA-mRNA Interactions. mSphere 5.

Wang Z, Mi Z, Wang H, Sun L, Yu G, Fu X, Wang C, Bao F, Yue Z, Zhao Q, Wang N, Cheng X, Liu H, Zhang F (2018) Discovery of 4 exonic and 1 intergenic novel susceptibility loci for leprosy. Clin Genet 94: 259-263.

Wei J, Pan X, Pei Z, Wang W, Qiu W, Shi Z, Xiao G (2012) The beta-lactam antibiotic, ceftriaxone, provides neuroprotective potential via anti-excitotoxicity and anti-inflammation response in a rat model of traumatic brain injury. J Trauma Acute Care Surg 73: 654-660.

Wendland JR, Moya PR, Timpano KR, Anavitarte AP, Kruse MR, Wheaton MG, Ren-Patterson RF, Murphy DL (2009) A haplotype containing quantitative trait loci for SLC1A1 gene expression and its association with obsessive-compulsive disorder. Arch Gen Psychiatry 66: 408-416.

Werner A, Amann E, Schnitzius V, Habermeier A, Luckner-Minden C, Leuchtner N, Rupp J, Closs EI, Munder M (2016) Induced arginine transport via cationic amino acid transporter-1 is necessary for human T-cell proliferation. Eur J Immunol 46: 92-103.

Werner A, Pieh D, Echchannaoui H, Rupp J, Rajalingam K, Theobald M, Closs EI, Munder M (2019) Cationic Amino Acid Transporter-1-Mediated Arginine Uptake Is Essential for Chronic Lymphocytic Leukemia Cell Proliferation and Viability. Front Oncol 9.

Williams BL, Yaddanapudi K, Hornig M, Lipkin WI (2007) Spatiotemporal analysis of purkinje cell degeneration relative to parasagittal expression domains in a model of neonatal viral infection. J Virol 81: 2675-2687.

Xing X, Chang LC, Kong Q, Colton CK, Lai L, Glicksman MA, Lin CL, Cuny GD (2011) Structureactivity relationship study of pyridazine derivatives as glutamate transporter EAAT2 activators. Bioorg Med Chem Lett 21: 5774-5777.

Yan TL, Wang M, Xu Z, Huang CM, Zhou XC, Jiang EH, Zhao XP, Song Y, Song K, Shao Z, Liu K, Shang ZJ (2017) Up-regulation of syncytin-1 contributes to TNF-alpha-enhanced fusion between OSCC and HUVECs partly via Wnt/beta-catenin-dependent pathway. Sci Rep-Uk 7.

Yeramian A, Martin L, Serrat N, Arpa L, Soler C, Bertran J, McLeod C, Palacin M, Modolell M, Lloberas 
J, Celada A (2006) Arginine transport via cationic amino acid transporter 2 plays a critical regulatory role in classical or alternative activation of macrophages. J Immunol 176: 5918-5924.

Yoon BR, Oh YJ, Kang SW, Lee EB, Lee WW (2018) Role of SLC7A5 in Metabolic Reprogramming of Human Monocyte/Macrophage Immune Responses. Front Immunol 9: 53.

Yu H, Yan H, Wang L, Li J, Tan L, Deng W, Chen Q, Yang G, Zhang F, Lu T, Yang J, Li K, Lv L, Tan Q, Zhang H, Xiao X, Li M, Ma X, Yang F, Li L, Wang C, Li T, Zhang D, Yue W, Chinese Antipsychotics Pharmacogenomics C (2018) Five novel loci associated with antipsychotic treatment response in patients with schizophrenia: a genome-wide association study. Lancet Psychiatry 5: 327-338.

Zhang Y, Zhang Y, Sun K, Meng Z, Chen L (2019) The SLC transporter in nutrient and metabolic sensing, regulation, and drug development. J Mol Cell Biol 11: 1-13.

Zhu XY, Cao YX, Su MY, Chen MM, Li CC, Yi L, Qin JJ, Tulake W, Teng FZ, Zhong YY, Tang WF, Wang SY, Dong JC (2021) Cycloastragenol alleviates airway inflammation in asthmatic mice by inhibiting autophagy. Mol Med Rep 24. 


\section{Footnotes}

This work is sopported by National Natural Science Foundation of China (32130048, 91857108 and 81470839 to L.C.), the Ministry of Science and Technology of China National Key R\&D Programs (2018YFA0506903 to L.C.), Nation Science and Technology Major Projects for Major New Drugs Innovation and Development (2018ZX09711003-004-002 to L.C.). The authors declare that there are no actual or perceived conflicts of interest with the contents of this article. 


\section{Figure legends}

Figure 1. Proposed roles of SLC1A1, SLC1A2 and SLC1A3 in the CNS. In neurons, glutaminase catalyzes the breakdown of glutamine (purple circle) to glutamate (green circle), which is transported illlllnto vesicles by VGLUTs and released into the synaptic space. SLC1A1, SLC1A2 re-uptake glutamate into neurons, and SLC1A2, SLC1A3 uptake glutamate into astrocytes, preventing excitotoxicity. Astrocytic glutamine is synthesized from glutamate catalyzed by GS, and then used by neurons. Agents that have been reported to stimulate or inhibit SLC1A1, SLC1A2 and SLC1A3 are presented. Microglia upon activation releases glutamate. VGLUTs, vesicular glutamate transporters; AMPAR, AMPA receptors; GS, glutamine synthetase; AEG-1, astrocyte elevated gene-1; JEV, Japanese encephalitis virus.

Figure 2. Proposed roles of SLC7 transporters in immune cells. In T cells, SLC7A1 transports arginine, SLC7A5/CD98 transports leucine, methionine, tryptophan, and other amino acids, and SLC7A11 transports glutamate. Leucine is essential for mTORC1 activation and c-Myc maintenance, and methionine is necessary for protein synthesis. Suppression of T cells by MDSCs is abolished by SLC7A2 deficiency. GSH production in part mediated by SLC7A11 can limit ROS accumulation and support the activity of mTOR and nuclear factor of activated T cells (NFAT) to drive glycolysis and glutaminolysis in activated T cells. Leucine is also required for NK cells. In macrophages, M1 or M2 activation both induce SLC7A2/CD98-dependent arginine transport. Mutation of SLC7A7 causes LPI and lowers phagocytic activity and NO production of macrophages. SLC7A11/CD98 transports cysteine and could be induced by M2 activation. SLC7A2 deficiency in colon causes more severe AOM-DSS-induced colitis and favors M2 macrophage activation. UC reduced chromosome-associated protein D3 (CAP-D3) upregulating SLC7A5/CD98 expression. MDSCs, myeloid-derived suppressor cells; AAs, amino acids; GSH, Glutathione; LPI, lysinuric protein intolerance; ROS, reactive oxygen species; AOM-DSS, azoxymethane-dextran sulfate sodium; UC, ulcerative colitis. * Figure created in biorender.com 


\begin{tabular}{|c|c|c|c|c|c|c|c|}
\hline $\begin{array}{l}\text { Human gene } \\
\text { name } \\
\text { DMD Fast Forward. }\end{array}$ & $\begin{array}{l}\text { Protein name } \\
\text { Published on February } 1\end{array}$ & $\begin{array}{l}\text { Aliases } \\
.2022 \text { as DOI: } 10\end{array}$ & $\begin{array}{l}\text { Substrates } \\
\text { nd.121.000705 }\end{array}$ & Transport type/ coupling ions & $\begin{array}{l}\text { Tissue distribution and } \\
\text { cellular/subcellular expression }\end{array}$ & Relevant molecular mechanisms & Sequence accession ID \\
\hline SLC1A1 & EAAC1, EAAC3 & System $X_{A G}^{-}$ & $\begin{array}{l}\text { Glutamate, } \\
\text { asparagine }\end{array}$ & $\mathrm{C} / \mathrm{Na}^{+}, \mathrm{H}^{+}$, and $\mathrm{k}^{+}$ & $\begin{array}{l}\text { Brain (neurons), lung, colorectal, } \\
\text { kidney, liver, heart, placenta }\end{array}$ & IFN- $\beta$ production: NF-kB pathway & NM_004170 \\
\hline SLC1A2 & GLT1, EAAT2 & System $X_{A G}^{-}$ & $\begin{array}{l}\text { Glutamate, } \\
\text { asparagine }\end{array}$ & $\mathrm{C} / \mathrm{Na}^{+}, \mathrm{H}^{+}$, and $\mathrm{k}^{+}$ & $\begin{array}{l}\text { Brain (astrocytes, bergmann glia, } \\
\text { neurons), liver, pancreas }\end{array}$ & Akt/mTORC pathway: NF-kB pathway & $\begin{array}{l}\text { NM_004171 } \\
\text { NM_001195728 } \\
\text { NM_001252652 }\end{array}$ \\
\hline SLC1A3 & GLAST, EAAT1 & System $X_{A G}^{-}$ & $\begin{array}{l}\text { Glutamate, } \\
\text { asparagine }\end{array}$ & $\mathrm{C} / \mathrm{Na}^{+}, \mathrm{H}^{+}$, and $\mathrm{k}^{+}$ & $\begin{array}{l}\text { Brain (astrocytes, bergmann glia), heart, } \\
\text { skeletal muscle, placenta }\end{array}$ & NF-kB; IGF-1; TLR-3; IFN- $\beta$ & $\begin{array}{l}\text { NM_004172 } \\
\text { NM_001166695 } \\
\text { NM_001166696 }\end{array}$ \\
\hline SLC1A4 & ASCT1, SATT & System ASC & $\begin{array}{l}\text { Cystine, serine, L- } \\
\text { Threonine }\end{array}$ & $\mathrm{C} / \mathrm{Na}^{+}$, E/amino acids & Widespread & iNOS & $\begin{array}{l}\text { NM_003038 } \\
\text { NM_001193493 }\end{array}$ \\
\hline SLC1A5 & ASCT2, AAAT & System ASC & $\begin{array}{l}\text { Asparagine, } \\
\text { glutamine }\end{array}$ & 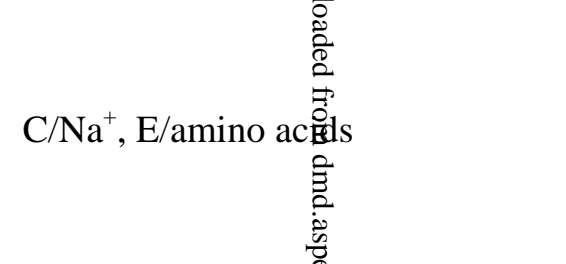 & $\begin{array}{l}\text { Adipose tissue, lung, skeletal muscle, } \\
\text { large intestine, kidney, testis }\end{array}$ & $\begin{array}{l}\text { Lck phosphorylation; TCR signaling; } \\
\text { NKG2D; IFN- } \gamma \text { production and } \\
\text { degranulation }\end{array}$ & $\begin{array}{l}\text { NM_005638 } \\
\text { NM_001145144 } \\
\text { NM_001145145 }\end{array}$ \\
\hline SLC7A1 & CAT-1 & System $\mathrm{y}^{+}$ & $\begin{array}{l}\text { Arginine, lysine, } \\
\text { ornithine }\end{array}$ & F (non-obligatory & $\begin{array}{l}\text { Ubiquitous except for liver and lacrimal } \\
\text { gland/basolateral and intracellular } \\
\text { membranes in epithelial cells }\end{array}$ & mTORC1 activity & NM_003045 \\
\hline SLC7A2 & CAT-2 & System $\mathrm{y}^{+}$ & $\begin{array}{l}\text { Arginine, lysine, } \\
\text { ornithine }\end{array}$ & 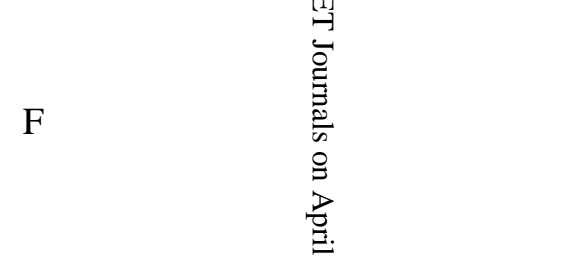 & $\begin{array}{l}\text { CAT-2A: liver, skeletal muscle, } \\
\text { pancreas; CAT-2B: inducible in many } \\
\text { cell types }\end{array}$ & NO production; NF-kB pathway & $\begin{array}{l}\text { NM_003046 } \\
\text { NM_001008539 }\end{array}$ \\
\hline SLC7A5 & LAT1 & System L & $\begin{array}{l}\text { Glutamine, leucine, } \\
\text { methionine, } \\
\text { tryptophan }\end{array}$ & 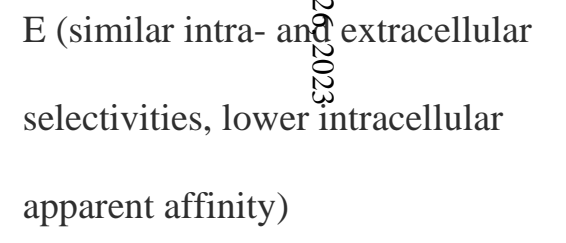 & $\begin{array}{l}\text { Brain, ovary, testis, placenta, spleen, } \\
\text { colon, blood-brain barrier, fetal liver, } \\
\text { activated lymphocytes, tumor cells }\end{array}$ & $\begin{array}{l}\text { c-Myc expression; IFN- } \gamma \text { production and } \\
\text { granzyme B expression }\end{array}$ & NM_003486 \\
\hline SLC7A7 & $\mathrm{y}^{+} \mathrm{LAT} 1$ & system $y^{+} \mathrm{L}$ & $\begin{array}{l}\text { Lysine, arginase, } \\
\text { ornithine, } \\
\text { methionine, leucine }\end{array}$ & $\begin{array}{l}\mathrm{Na}^{+} \text {dependent transport of } \\
\text { extracellular large neutral L-amino } \\
\text { acids }\end{array}$ & $\begin{array}{l}\text { Small intestine, kidney, spleen, } \\
\text { leucocytes, placenta, lung/basolateral in } \\
\text { epithelial cells }\end{array}$ & NO production; NF-kB pathway & NM_003982 \\
\hline
\end{tabular}


SLC7A11 $\quad x C T$
Cystine, glutamate cystine against intracellular

glutamate)
Glutathione production; ROS

accumulation; mTOR and NFAT activity; NM_014331

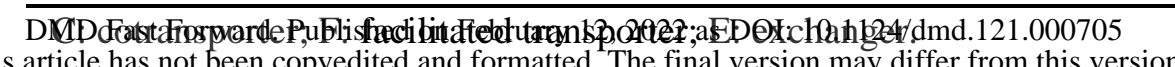

Table2 Specific inhibitors associated with SLC1 and SLC7 transporters

\begin{tabular}{|c|c|c|c|c|}
\hline Human gene name & Inhibitor & Formula & $\mathrm{IC}_{50}$ & Reference \\
\hline \multirow[t]{4}{*}{ SLC1A2 } & WAY-213613 & $\mathrm{C}_{16} \mathrm{H}_{14} \mathrm{BrClF}_{2} \mathrm{~N}_{2} \mathrm{O}_{4}$ & $0.085 \mu \mathrm{M}$ & (Simmons et al,2014) \\
\hline & DL-TBOA & $\mathrm{C}_{11} \mathrm{H}_{13} \mathrm{NO}_{5}$ & $6 \mu \mathrm{M}$ & (Pedraz-Cuesta et al,2015) \\
\hline & Dihydrokainic acid (DHK) & $\mathrm{C}_{10} \mathrm{H}_{17} \mathrm{NO}_{4}$ & $23 \mu \mathrm{M}\left(\mathrm{K}_{\mathrm{i}}\right)$ & (Arriza et al,1994) \\
\hline & T3MG & $\mathrm{C}_{6} \mathrm{H}_{11} \mathrm{NO}_{4}$ & $90 \mu \mathrm{M}$ & (Eliasof et al,2001) \\
\hline \multirow[t]{4}{*}{ SLC1A3 } & UCPH-101 & $\mathrm{C}_{27} \mathrm{H}_{22} \mathrm{~N}_{2} \mathrm{O}_{3}$ & $0.66 \mu \mathrm{M}$ & (Abrahamsen et al,2013) \\
\hline & UCPH-102 & $\mathrm{C}_{21} \mathrm{H}_{18} \mathrm{~N}_{2} \mathrm{O}_{2}$ & $0.42 \mu \mathrm{M}$ & ( Ha产商 et al,2016) \\
\hline & DL-TBOA & $\mathrm{C}_{11} \mathrm{H}_{13} \mathrm{NO}_{5}$ & $70 \mu \mathrm{M}$ & 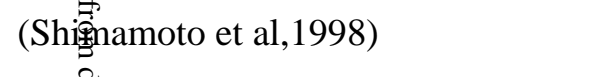 \\
\hline & WAY-213613 & $\mathrm{C}_{16} \mathrm{H}_{13} \mathrm{BrF}_{2} \mathrm{~N}_{2} \mathrm{O}_{4}$ & $5 \mu \mathrm{M}$ & 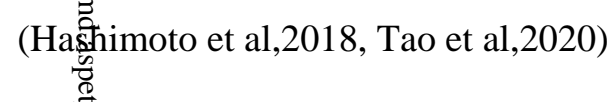 \\
\hline \multirow[t]{3}{*}{ SLC1A5 } & Lobetyolin & $\mathrm{C}_{20} \mathrm{H}_{28} \mathrm{O}_{8}$ & N/A & $(\mathrm{He} \underset{\mathrm{w}}{\mathrm{d}} \mathrm{tal}, 2020)$ \\
\hline & V-9302 & $\mathrm{C}_{34} \mathrm{H}_{38} \mathrm{~N}_{2} \mathrm{O}_{4}$ & $9.6 \mu \mathrm{M}$ & (Sc) \\
\hline & GPNA hydrochloride & $\mathrm{C}_{11} \mathrm{H}_{14} \mathrm{ClN}_{3} \mathrm{O}_{5}$ & $55 \mu \mathrm{M}\left(\mathrm{K}_{\mathrm{i}}\right)$ & (Com et al,2019) \\
\hline SLC7A2 & Platonin & N/A & N/A & 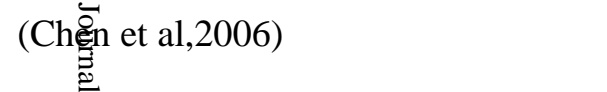 \\
\hline \multirow[t]{5}{*}{ SLC7A5 } & $\mathrm{BCH}$ & $\mathrm{C}_{8} \mathrm{H}_{13} \mathrm{NO}_{2}$ & $131.5 \mu \mathrm{M}$ & 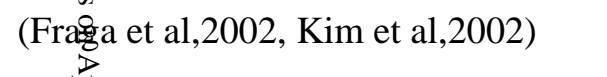 \\
\hline & КМH-233 & $\mathrm{C}_{32} \mathrm{H}_{25} \mathrm{~N}_{7} \mathrm{O}_{5}$ & $18 \mu \mathrm{M}$ & (Huțtunen et al,2016) \\
\hline & GPNA hydrochloride & $\mathrm{C}_{11} \mathrm{H}_{14} \mathrm{ClN}_{3} \mathrm{O}_{5}$ & $250 \mu \mathrm{M}$ & (Cơ⿱山口, et al,2019) \\
\hline & Lats-IN-1 & $\mathrm{C}_{18} \mathrm{H}_{14} \mathrm{~N}_{4} \mathrm{OS}$ & $0.51 \mu \mathrm{M}\left(\mathrm{EC}_{50}\right)$ & (Kastan et al,2021) \\
\hline & JPH203 & $\mathrm{C}_{23} \mathrm{H}_{19} \mathrm{Cl}_{2} \mathrm{~N}_{3} \mathrm{O}_{4}$ & $0.14 \mu \mathrm{M}$ & (Oda et al,2010) \\
\hline
\end{tabular}




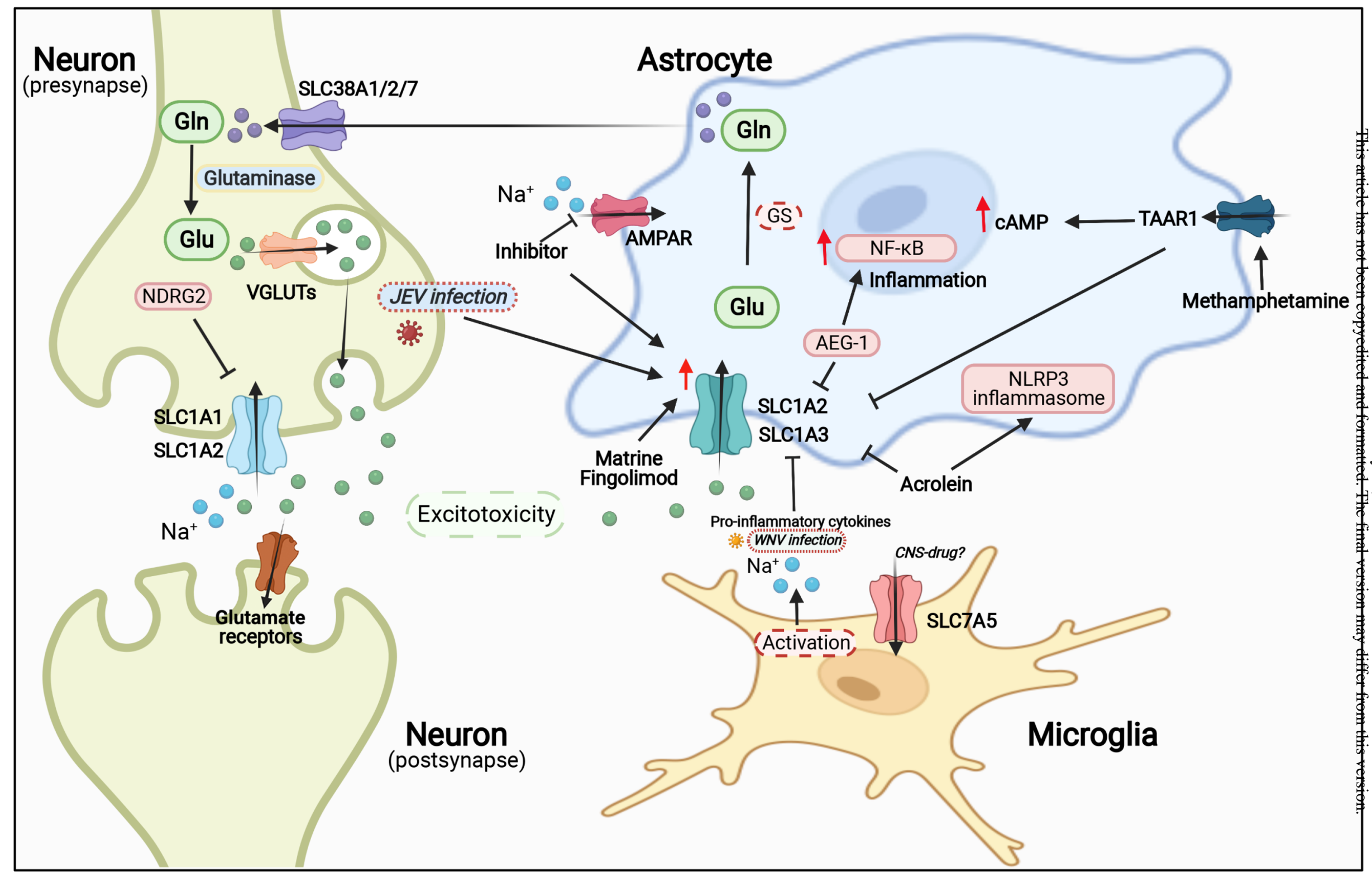

Figure 1 


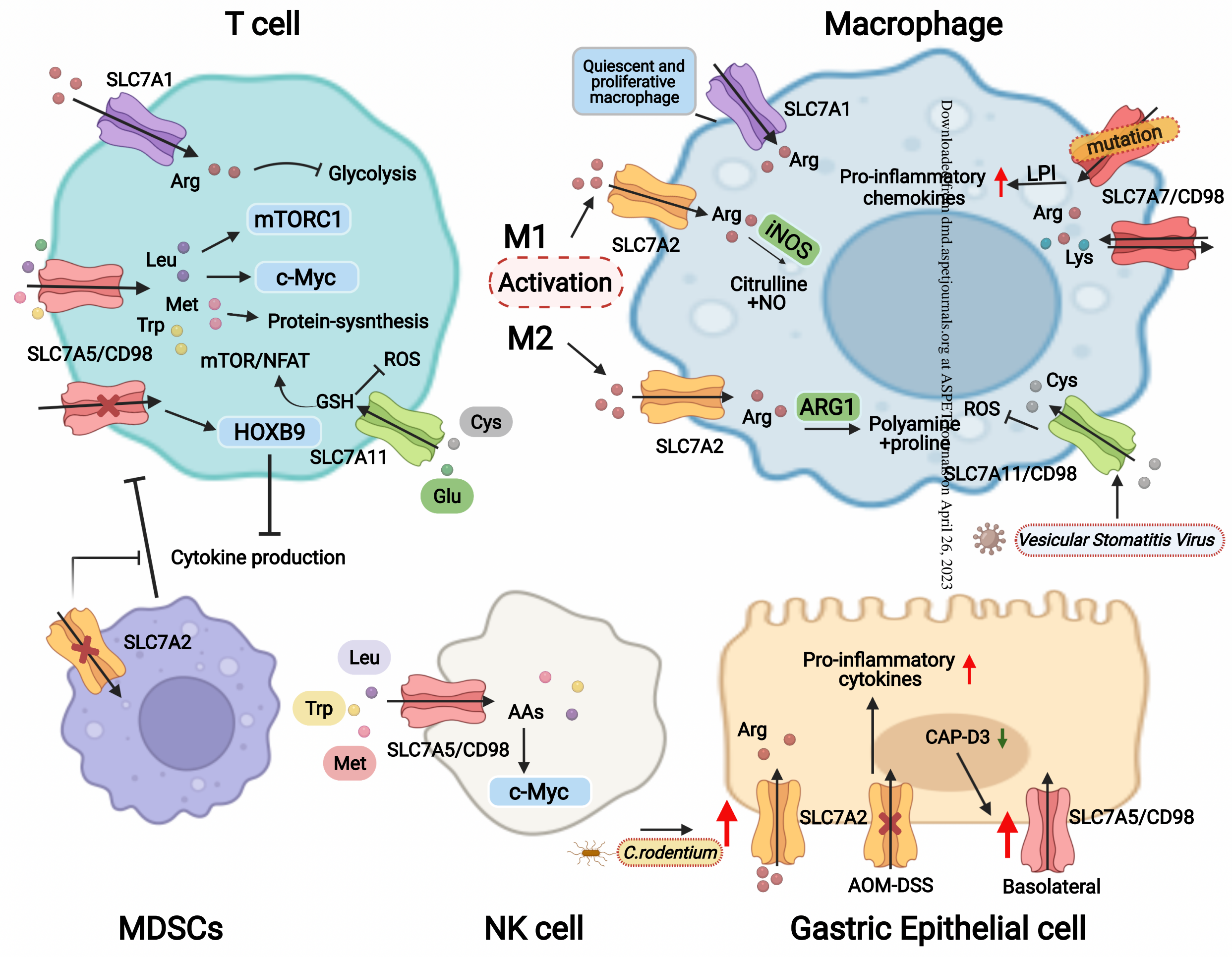

